\title{
ARCHITECTURE
}

\section{ENERGY-EFFICIENT INDOOR LIGHT ENVIRONMENT: A DEFINITION}

\section{Lidiia Koval $^{1}$}

DOI: https://doi.org/10.30525/978-9934-26-050-6-69

Indoor lighting design is an organic component of light design in general. The profession of a light designer as an independent project practice was shaped owing to the creation of the International Association of Lighting Designers (IALD) in 1969 [1]). Lighting design is defined as a new phenomenon in the art of creating an appropriately comfortable and artistically expressive living environment. Modern lighting design is based on people's aesthetic perception, ergonomic aspect and energy efficiency of lighting. Therefore, the creation of a comfortable lighting environment in compliance with modern requirements for energy efficiency is prioritized in the light design. Given this, it is necessary to define such a concept as an «energy-efficient indoor light environment.» This definition can be formulated based on a detailed analysis of the known definitions of «energy efficiency» and «light environment».

Thus, according to State Building Code of Ukraine (DBN B.2.5-28-2018), «light environment is a set of ultraviolet, visible, infrared radiations of natural and artificial light sources; an important component of organisms and plants living environment, determined by the light fluxes of light sources, changing as a result of interaction with the subject environment; it is visually perceived by the distribution of light in space [12, p. 6]». From the point of view of occupational health, «the light environment is a background physical stimulus of low intensity, which has both general biological and specific action [9]». In the hygienic context, the concept of «light environment» is closely related to the concept of «visual comfort», which expresses «harmonious satisfaction in the subjective need for light, which contributes to the formation of a high level of body functionality, providing distinct visibility of objects at the slightest fatigue, creating a subjective sense of well-being [9]».

If we resort to the interpretation of the light environment in terms of such industries as architecture and design, it is defined as:

\footnotetext{
${ }^{1}$ Zaporizhzhya National University, Ukraine
} 
- «spatial formation with a certain subject content, whose purpose is to maintain the basic processes of human life: work, life, recreation [4]»;

- «a set of ultraviolet, visible and infrared radiations generated by natural and artificial light sources, as well as space (light space) filled with this light and illuminated objects (light forms) [8; 2, p. 158]».

In the context of environmental design, the concept of «light environment» is closely related to the concept of «light climate», which expresses «a set of conditions that ensure normal visual performance: sufficient intensity of general lighting and optimal illumination of work surfaces; uniform distribution of light intensity and permissible brightness distribution in the field of view; normal conditions for shadowing; rational spectral characteristics of light flux [2, p. 158; 11]».

From the point of view of physics, «narrowly, light is electromagnetic waves that are perceived by the human eye. The wavelength of light is within the range from about 0.4 to $0.76 \mu \mathrm{m}$. In a broader sense, the light also includes infrared and ultraviolet parts of the electromagnetic spectrum [3, p. 278]». As part of the indoor light design study, the light should be narrowly defined as electromagnetic waves of the visual range.

Taking into account the above-mentioned variants of «light environment» definitions in various industries, we formulate it in terms of the light design. Thus, an indoor light environment is understood as a spatial formation filled with visible radiations generated by natural and/or artificial light sources and consisting of direct, transmitted, scattered and reflected rays, whose combination provides a proper light microclimate, normal visual performance and ophthalmic comfort of a person.

It is also necessary to consider the definition of the «energy efficiency» concept. Around the globe, the official documents, which relate to strategies and ways to improve energy efficiency in various sectors of human life, interpret this concept as follows:

- energy efficiency is the ratio of output productivity, services, goods or energy to input energy [5];

- energy efficiency is a measure of the amount of useful work that can be obtained in the system from a given amount of input energy, and improving energy efficiency means achieving a certain goal using less energy [10, p. 36, 315-316];

- energy efficiency is determined in terms of engineering and economic principles of managing direct and indirect energy costs without deteriorating performance, its task is to maximize the output of each unit of energy consumed or achieve the same output with less energy [6, p. 119].

Energy efficiency is often defined from the standpoint of using modern technologies to reduce the amount of energy consumed while providing a 
given level of service, although energy-efficient technologies in many cases have additional "non-energy» benefits that improve service levels. In some cases, the value of these non-energy benefits exceeds the value of energy savings obtained during the life of the product. It is also possible that energyefficient technologies can reduce the level of service quality, however, the number of such cases is scarce [10, p. 107-109].

The energy efficiency of artificial lighting can be expressed as a dimensionless quantity, as the ratio of energy consumed by the light source to the light energy emitted by it [10, p. 36]. The efficiency of indoor lighting is estimated by the consumption of electricity for lighting $1 \mathrm{~m}^{2}$ of the area. The universal criterion for assessing the efficiency of energy saving in lighting is the ratio between the cost of modernization of lighting equipment and the cost of saved electricity. Besides, one of the criteria for energy efficiency of lighting is the power consumed to illuminate $1 \mathrm{~m}^{2}$ of the surface, attributed to $100 \mathrm{~lx}$ at $100 \%$ efficiency of the luminaire and a stock factor of 1.5 [7, p. 281].

At the same time, the term «energy-efficient architecture» means «a complex of rational architectural and construction solutions, engineering equipment and technological systems in buildings and structures that provide conditions which are favorable for human life and the organization of functional and technological processes, due to the use of rational spaceplanning solutions and special equipment for receiving, converting and transmitting energy from renewable sources [2, p. 93-94]».

Thus, based on the analyzed components, it is possible to offer a full definition of the concept: an energy-efficient indoor light environment is a light environment created as a result of project activities, with the use of both natural and artificial light. Its specificity is secured by the fact that it includes a set of rational lighting solutions and technological systems that provide a reduction in direct and indirect costs for indoor lighting without compromising its quality, creating human-friendly conditions and implementing functional and technological processes.

\section{References:}

1. 50th Anniversary Year. Celebrating a Half Century of IALD and Lighting Design (2019) IALD. Retrieved from: https://www.iald.org/About/About-theIALD/50th-Anniversary-Year (accessed 10 February 2021).

2. Agranovich-Ponomareva E. S. (ed.) (2009) Arkhitekturnyy dizayn [Architectural design]. Rostov on Don: Feniks. (in Russian)

3. Bilenko I. I., Zhmudskyi O. Z. (ed.) (1979) Fizychnyi slovnyk [Physical dictionary]. Kyiv: Vyshcha shkola. (in Ukrainian)

4. Dubynskyi V. P. (2007) Arkhitekturno-khudozhni pryntsypy formuvannia svitlokolorovoho seredovyshcha suchasnoho mista [Architectural and artistic principles of 
formation of light and color environment of the modern city] (Phd Thesis), Kharkiv: Kharkiv State Technical University of Construction and Architecture.

5. Erbach G. (2015) Understanding energy efficiency. European Parliamentary Research Service (EPRS). Members' Research Service PE 568.361. Retrieved from: http://www.europarl.europa.eu/RegData/etudes/BRIE/2015/568361/EPRS_BRI(2015) 568361_EN.pdf (accessed 10 February 2021).

6. Gulf Organization for Industrial consulting (2013) Energy Efficiency Guidebook. A GOIC publicatin for GCC industries, Doha Qatar: Gulf Organization for Industrial consulting.

7. Gvozdev S. M., Panfilov D. I., Romanova T. K. \& others, Varfolomeev L. P. (ed.) (2013) Energoeffektivnoe elektricheskoe osveshchenie [Energy efficient electric lighting]. Moscow: Izdatel'skiy dom MEI. (in Russian)

8. Litskevich V. K., Makrinenko L. I., Migalina I. V. \& others, Obolenskiy N. V. (ed.) (2007) Arkhitekturnaya fizika [Architectural physics]. Moscow: «Arkhitektura-S». (in Russian)

9. Martirosova V. G. (2017) Oftal'mologicheskie i svetotekhnicheskie perspektivy vnedreniya svetodiodnykh istochnikov sveta na proizvodstvennykh predpriyatiyakh Ukrainy [Ophthalmological and lighting technical prospects for the introduction of LED light sources at industrial enterprises of Ukraine]. Proceedings of the LED Progress (Ukraine, Kyiv, September 13-15, 2017). Retrieved from: http://ualedlight.org/images/LedExpo2017 /1/Martirosova.pdf (accessed 10 February 2021).

10. National Academy of Sciences USA (2010) Real Prospects for Energy Efficiency in the United States. Washington: National Academy of Sciences USA.

11. Ponomareva E. S. (1991) Inter'er grazhdanskikh zdaniy [Interior of civilian buildings]. Minsk: Vysheyshaya shkola. (in Russian)

12. Ukrarkhbudinform (2018) DBN V.2.5-28-2018. Pryrodne i shtuchne osvitlennia [Natural and artificial lighting]. Kyiv: Ukrarkhbudinform. (in Ukrainian) 